Gut, 1963, 4, 292

\title{
Acute folic acid deficiency of unknown aetiology: temperate sprue
}

\author{
W. T. COOKE, D. J. FONE, E. V. COX, M. J. MEYNELL, \\ AND R. GADDIE
}

From the General Hospital, Birmingham

EDITORIAL SYNOPSIS The 20 patients described could be included in the group of patients diagnosed as 'idiopathic steatorrhoea'. However, their histories were short and diarrhoea was not a major feature. Since megaloblastic anaemia due to folic acid deficiency was a common feature it is suggested that these patients may form a homogeneous group and the diagnostic label of temperate sprue is suggested.

In the previous paper, Cooke, Fone, Cox, Meynell, and Gaddie (1963) described the life history, laboratory findings, and response to therapy in a group of patients with 'flat' jejunal biopsies, fulfilling the criteria for diagnosis of idiopathic steatorrhoea (Cooke, Peeney, and Hawkins, 1953). These patients have been designated as suffering from adult coeliac disease (Cooke, 1958; Fone, Cooke, Meynell, Brewer, Harris, and Cox, 1960). The purpose of this paper is to present the findings of a second group, also fulfilling criteria for the diagnosis of idiopathic steatorrhoea, which is associated with severe megaloblastic anaemia responsive to folic acid, together with jejunal biopsies and certain laboratory tests which are significantly different from those found in adult coeliac disease. The methods used in the investigations have been given in an earlier paper (Cooke et al., 1963).

\section{CLINICAL MATERIAL}

There were 15 women and five men whose ages ranged from 14 to 75 years (Fig. 1).

\section{SYMPTOMS}

Symptoms were of recent onset varying from two weeks to six months. Lassitude, shortness of breath, and loss of weight were the principal complaints. Weight loss was usually 7 to $10 \mathrm{lb}$. though in two cases was as much as $20 \mathrm{lb}$. in the course of three months. Sore tongue was a complaint in 14 of the 20 patients. Diarrhoea was one of the main presenting features in only two patients, though the presence of loose stools or frank diarrhoea of recent onset was elicited on questioning in 15 others. In none were

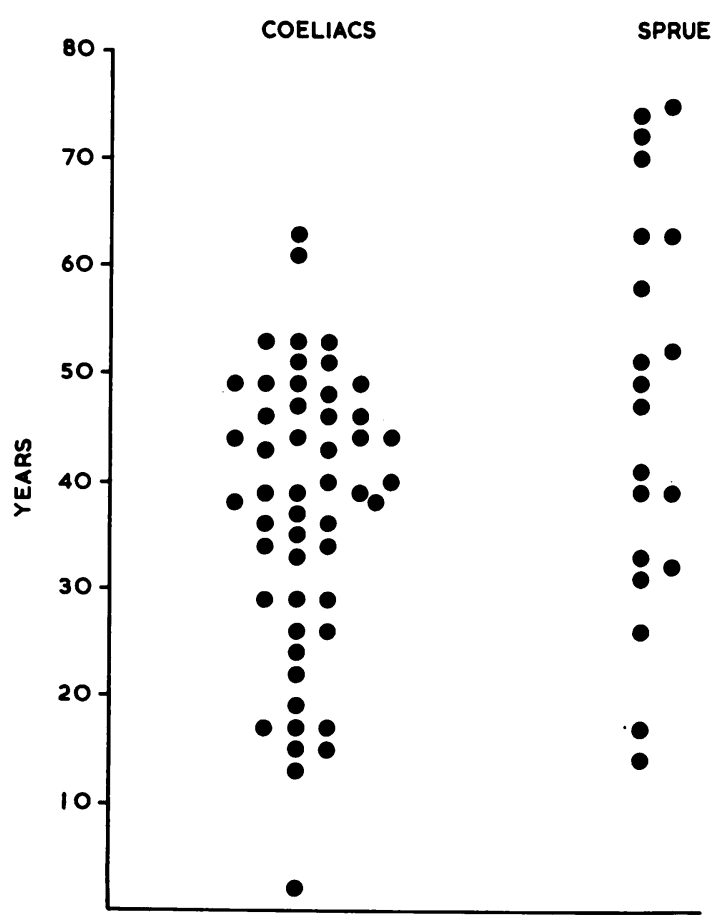

FIG. 1. Age presentation of 20 patients with acute folic acid deficiency ('sprue'), compared with 50 patients with adult coeliac disease.

there the symptoms or signs of osteomalacia or neuropathy.

Eighteen of the 20 patients had normal dietary habits. Two patients, aged 47 and 50 respectively, ate animal protein on rare occasions only but in each case the dietary protein from other sources varied 
between 50 and $55 \mathrm{~g}$. daily. Neither was clinically malnourished.

\section{INVESTIGATIONS}

JEJUNAL BIOPSY Jejunal biopsy was carried out on all patients but was unsuccessful in one (case 4) despite repeated attempts. This patient has been included since she had normal folic acid absorption and excretion tests, normal glucose tolerance, and mild steatorrhoea.

Examination under the dissecting microscope showed much variation in appearance from one patient (case 1) with 'convolutions' to those with 'leaves' and oedematous villi (Fig. 2). Light microscopy showed villi in all. The surface epithelial cells and brush borders appeared normal, contrasting strikingly with those seen in adult coeliac disease. The villi were broader than those in the normal subject. In two patients, there was a moderately heavy infiltration of chronic inflammatory cells in the substantia propria, consisting mainly of plasma cells. In most patients, the villi appeared mildly oedematous. In three patients, the villi were virtually normal. Characteristic sections are shown in Figure 3.

FAECAL FAT Steatorrhoea was present in 12 patients. Of five patients in whom the findings were checked in remission more than two years later, three still had steatorrhoea. Of the eight patients who did not excrete excess fat, three had had a history of attacks of diarrhoea with pale stools but at the time of testing had no steatorrhoea.

HAEMATOLOGY The haematological findings are shown in Table I. The mean figures were red blood cells 1,570,000 (S.E. 110,000) per c.mm., haemoglobin 37 (S.E. $1 \cdot 2 \%$ ), white blood cells 3,400 (S.E. 290) per c. mm., M.C.V. 107 (S.E. 2.6) c.u., M.C.H.C. 32.8 (S.E. $0.7 \%$ ). These compare with a mean red cell count $3,880,000$ (S.E. 130,000 ) per c.mm., haemoglobin 77.8 (S.E. $2.7 \%$ ), white blood cells, 6,210 (S.E. 375) per c.mm., M.C.V. 95 (S.E. 2-1) c.u., M.C.H.C. $30 \cdot 4$ (S.E. $0 \cdot 46 \%$ ) found in 50 patients when first seen suffering from adult coeliac disease. Examination of the sternal marrow showed megaloblastic erythropoiesis in every patient.

FOLIC ACID METABOLISM The mean folic acid excretion test index in 19 patients was $67 \%$. Six of these were within the normal range (Fig. 4). This index was significantly higher than that found in 33 patients with adult coeliac disease $(P<0.001)$. Folic acid absorption tests were carried out on seven patients and were significantly different from those with adult coeliac disease and not greatly different from those found in normal subjects (Fig. 5).

GASTRIC ANALYSIS Free acid was present in the gastric contents of all the patients.

B12 METABOLISM All except case 1 had normal hepatic uptakes of $58 \mathrm{CoB} 12$ following oral administration.

TABLE I

MAIN LABORATORY FINDINGS ON PRESENTATION

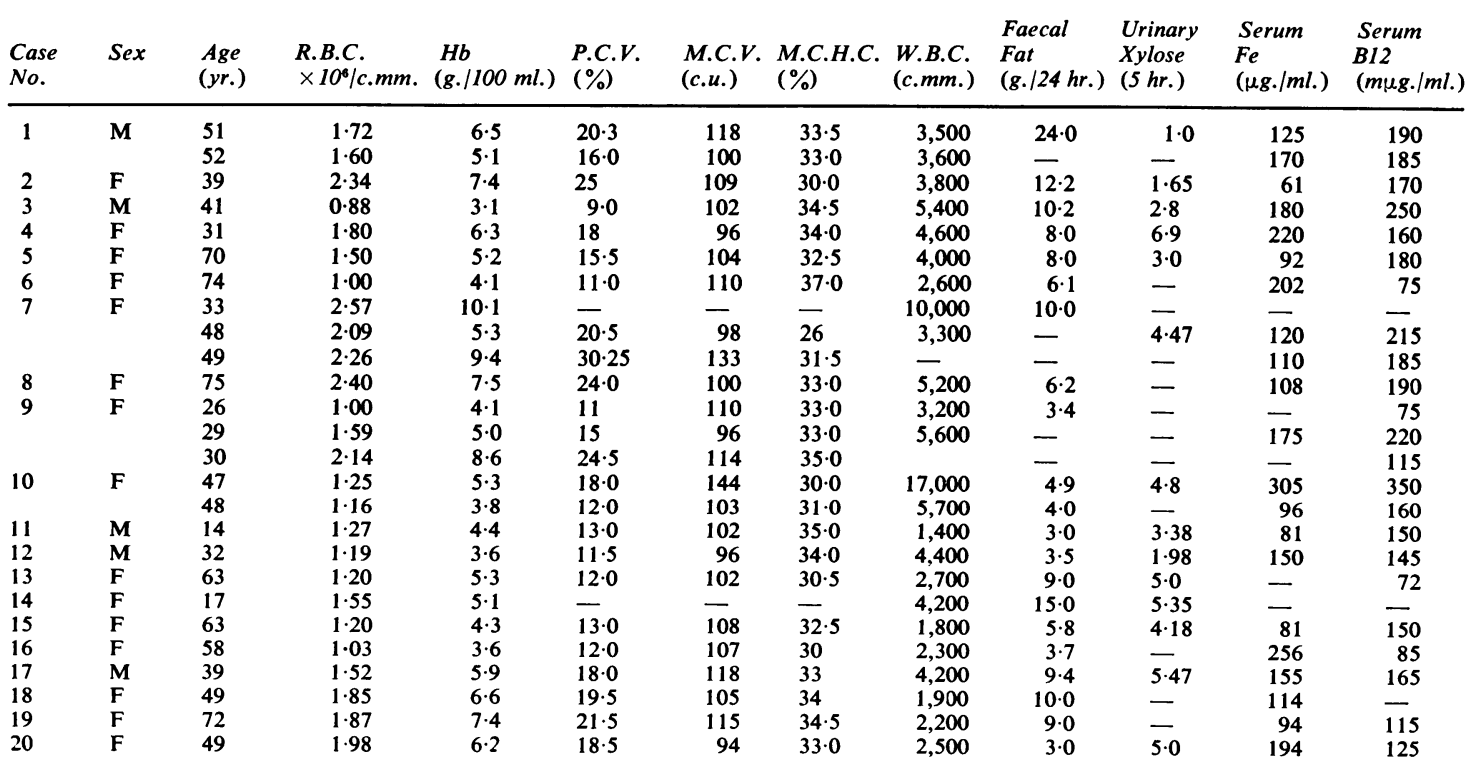




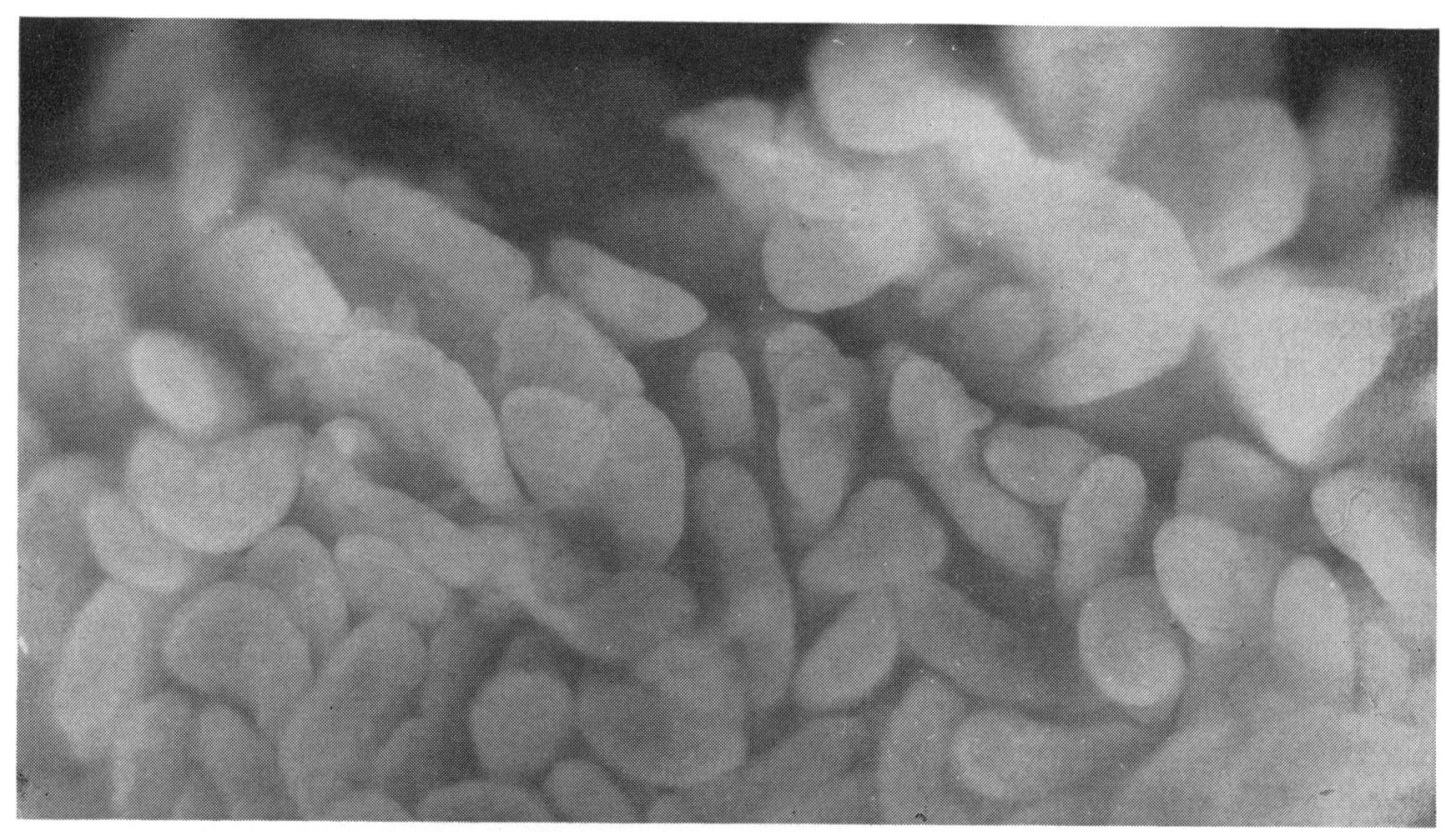

CASE 10

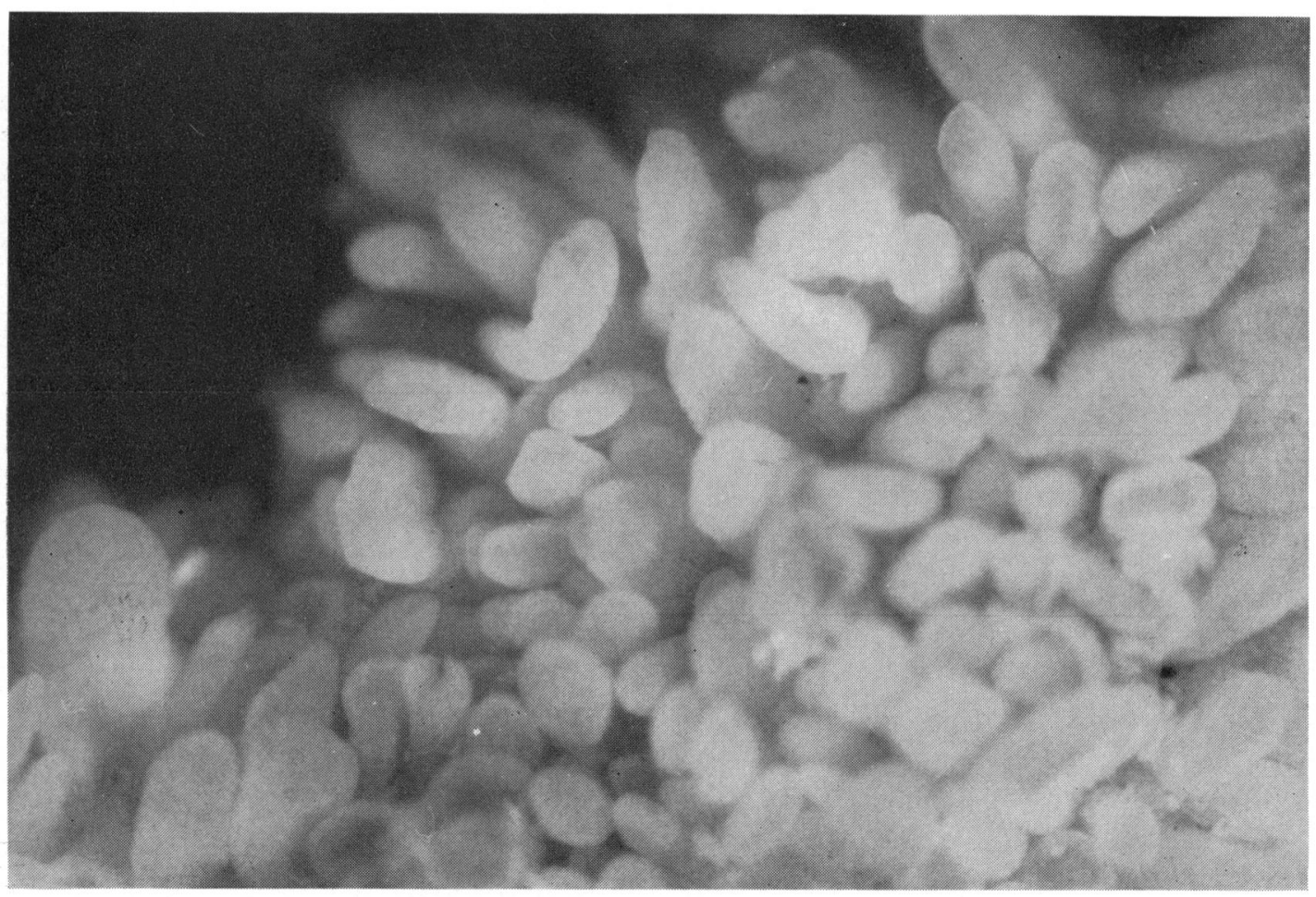

CASE 13

FIG. 2. Macroscopic view of the jejunal surface showing essentially normal appearance (cases 10 and 13). 


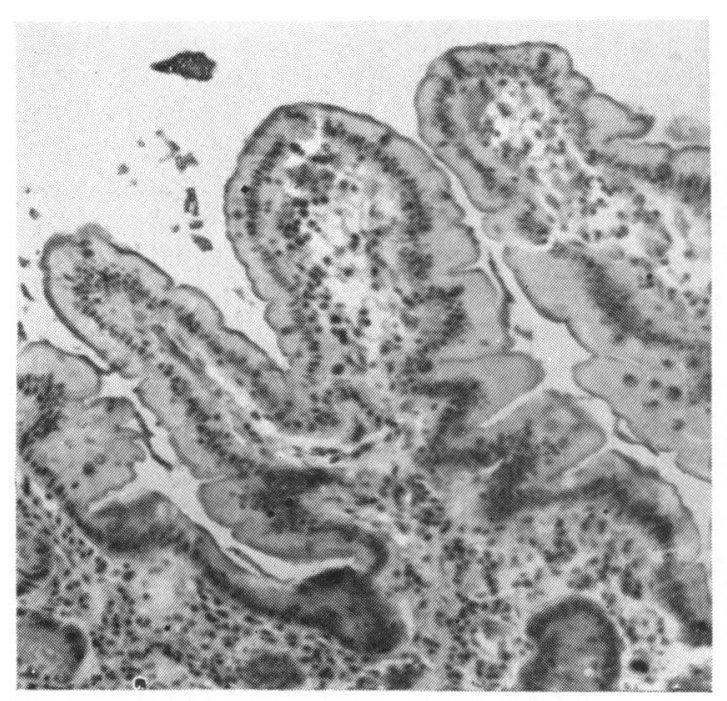

CASE 3

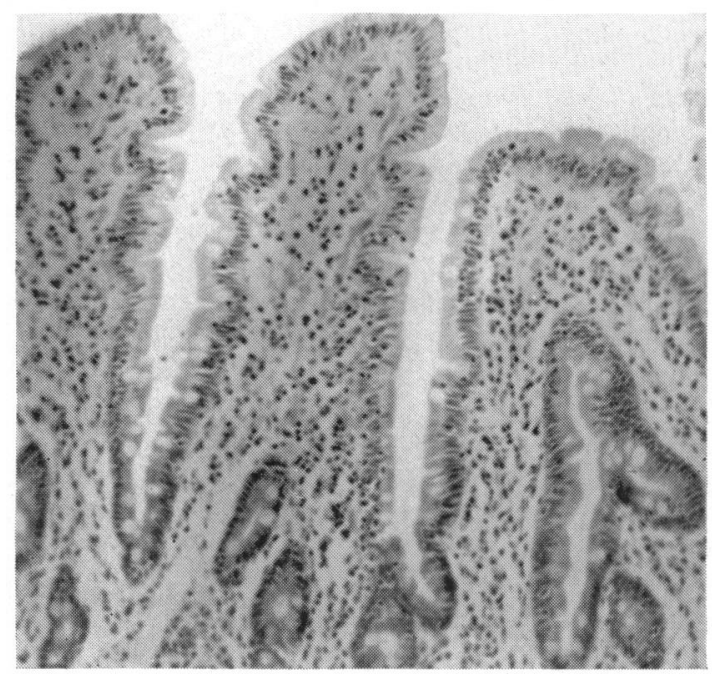

CASE 8

FIG. 3. Jejunal biopsies of cases 3, 6,8, and 12 showing the presence of villi with normal surface epithelium.

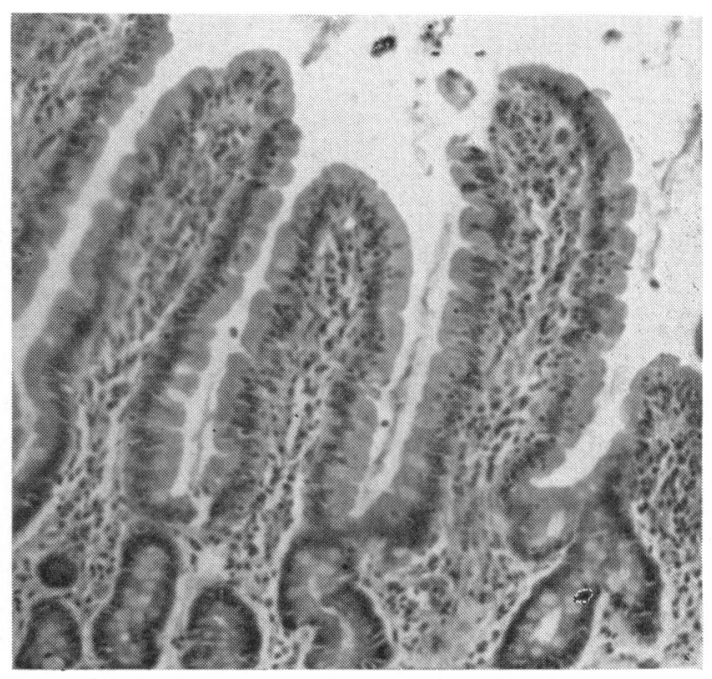

CASE 6

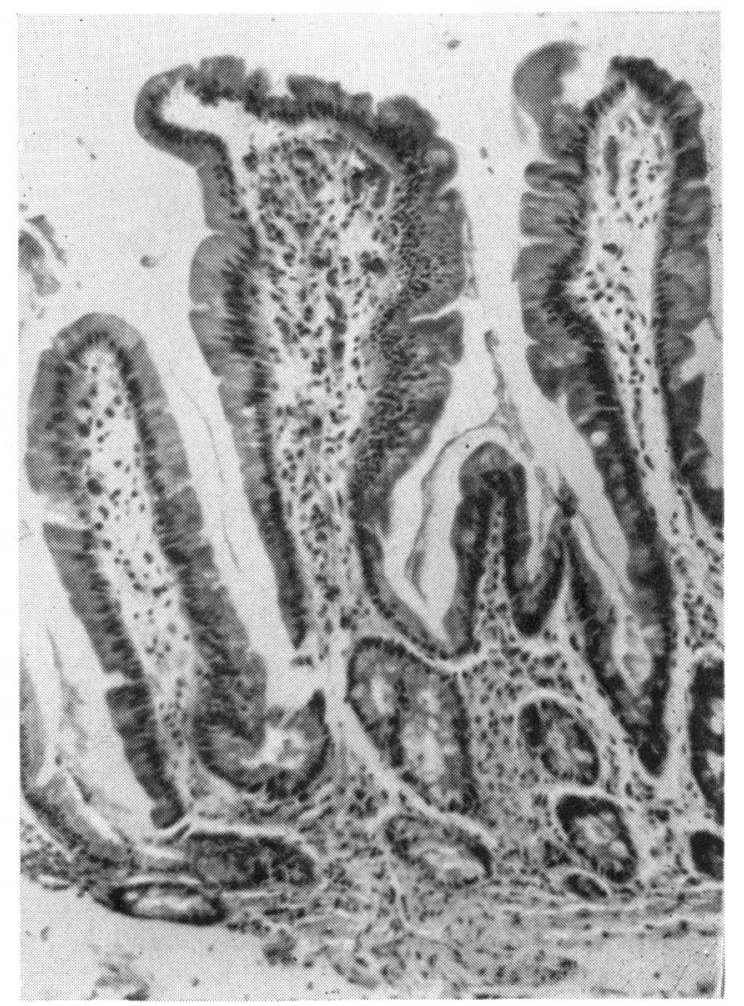

CASE 12 


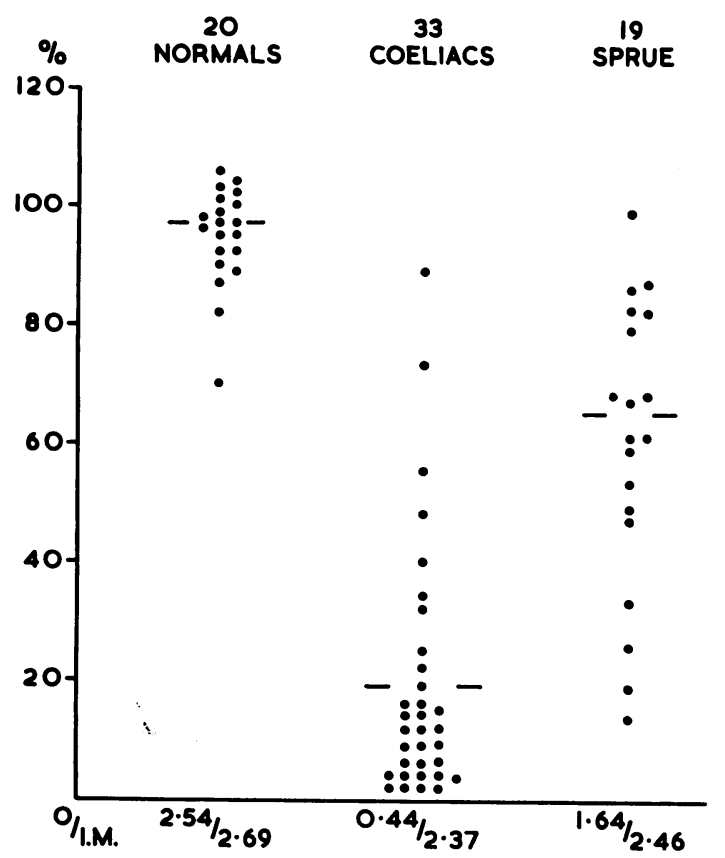

FIG. 4. Folic acid excretion index in 'sprue' patients compared with that in 33 patients with adult coeliac disease.

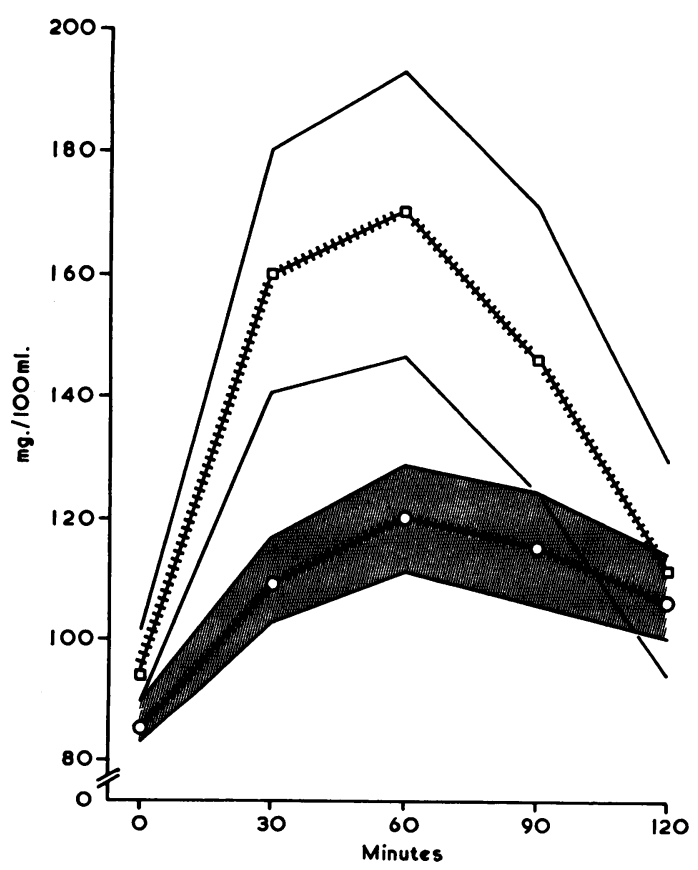

FIG. 6. Glucose tolerance tests in sprue patients compared with those in adult coeliac disease.
Case 1 failed to absorb B12 normally even with the addition of intrinsic factor. He was studied on two occasions with a severe megaloblastic anaemia of relatively rapid onset. On neither occasion did he respond to intramuscular injections of vitamin B12. He had the most marked steatorrhoea ( 24 g. per 24 hr.) of the patients in this group. His folic absorption curve was normal whilst the folic acid excretion index was just subnormal $62 \%(2 \cdot 74 / 1 \cdot 72)$.

The initial levels of serum B12 of all the patients were mainly in the lower range of normal (Table I). Five patients had subnormal levels $(<150 \mu \mathrm{g} . / \mathrm{ml}$.) In case 7 , folic acid therapy caused a further fall in the

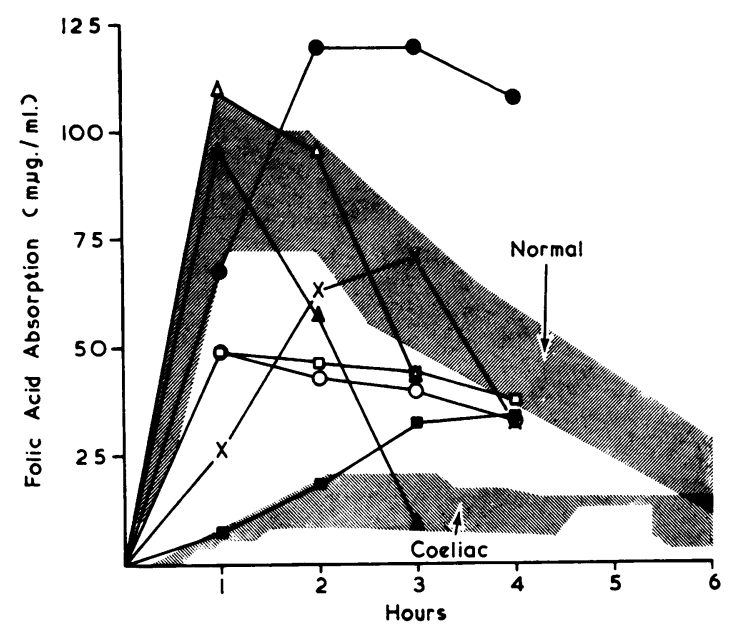

FIG. 5. Folic acid absorption tests in seven patients with acute folic acid deficiency. The stippled times enclosed the mean and two standard errors of the mean for normal subjects and for 15 patients with adult coeliac disease.

serum level of B12 but in each patient with the restoration of normal blood values the concentration of B12 in the serum returned to normal (Cox, Cooke, Meynell, and Gaddie, 1962; Johnson, Swaminathan, and Baker, 1962).

SERUM IRON Whilst raised serum levels of iron were noted in four patients, the majority of values fell within the normal range, though they were lower than are usually encountered in pernicious anaemia in relapse. Following the initial treatment, 14 patients became iron deficient and needed oral iron to ensure complete restoration of normal blood values.

CARBOHYDRATE METABOLISM Eight of the 14 patients in whom the d-xylose excretion test was performed excreted more than $4.2 \mathrm{~g}$. in five hours as compared with four out of 29 with adult coeliac disease. Glucose tolerance tests were performed on 13 patients. These were comparable to those found in 
normal subjects and significantly different from those found in adult coeliac disease (Fig. 6).

PROTEINS The mean serum albumin level was 3.77 (S.E. 0.17) g. per $100 \mathrm{ml}$. Five of 19 patients had levels of less than $3.5 \mathrm{~g}$. per $100 \mathrm{ml}$. These findings were comparable to the mean level in adult coeliac disease of 3.66 (S.E. 0.13) g. per $100 \mathrm{ml}$. The mean serum globulin was 2.66 (S.E. 0.11) g. per $100 \mathrm{ml}$. which was lower than that encountered in adult coeliac disease $2 \cdot 88$ (S.E. 0.11) g. per $100 \mathrm{ml}$.

CAlcium, Phosphorus, Phosphatase Nine of the 12 patients in whom calcium levels were determined initially had values less than $9.4 \mathrm{mg}$. per $100 \mathrm{ml}$. Serum phosphorus values fell within the normal range whilst two patients (cases 6 and 15) had alkaline phosphatase values greater than 12 King-Armstrong units.

RADIOLOGY Examination of the small intestine was carried out in all the patients. It was normal in three: the remainder showed varying degrees of dilatation comparable in every respect with that seen in patients with adult coeliac disease.

\section{RESPONSE TO THERAPY}

Thirteen patients received saturating doses (1 to 5 $\mathrm{mg}$.) of vitamin B12. Six of these showed no response, assessed by lack of reticulocyte increase and fall in serum iron, and the red cell count and haemoglobin continued to fall. Two who similarly showed no response still had megaloblastic erythropoiesis following therapy. Of the remaining five, three produced a slight rise in reticulocytes but without increase in red cell count or haemoglobin or fall in serum iron. Case 9 had a partial remission with B12 and blood transfusion but needed the addition of folic acid to complete the response. On a subsequent occasion the administration of Cytamen by her local practitioner one week before admission in severe relapse did not remove megaloblasts from the bone marrow. These 12 patients achieved haemotological remission with folic acid but one patient (case 17) achieved full remission with B12 alone. Two patients (cases 7 and 15) whose illnesses started 20 years ago responded to crude liver extract. One (case 7) relapsed subsequently on two occasions and both patients have been shown to respond to folic acid.

Five patients achieved rapid rise in reticulocytes, fall in serum iron, and rise in blood values following the intramuscular administration of leucovorin, 5 $\mathrm{mg}$. In two of these patients (cases 11 and 12) $5 \mathrm{mg}$. folic acid intramuscularly and $5 \mathrm{mg}$. folic acid orally administered for the folic acid excretion test was the only other therapy necessary to achieve full haematological remission and still maintain it more than three years after the initial therapy.

On the other hand four patients (cases 1, 7, 9, and 10), for various reasons have relapsed on six occasions. Their subsequent response to further folic acid therapy has been essentially the same as in their initial illness. All are now convinced of the need for regular therapy. The remainder have been in good health and with normal blood counts with regular therapy with folic acid. More detailed observations on this group of patients with respect to folic acid metabolism will be presented elsewhere. Though 14 showed varying degrees of iron deficiency which needed correction before full haematological remission was obtained, there was need for subsequent iron therapy in only two (cases 2 and 7 ).

\section{DISCUSSION}

This group of 20 patients, many of whom fulfil criteria for the diagnosis of 'idiopathic steatorrhoea', have features which contrast with those found in patients with adult coeliac disease (Cooke et al., 1963). The clinical histories are short and diarrhoea is not a major feature. The jejunal biopsies were different to those found in adult coeliac disease and in some patients might be thought to be normal. It might be argued that they are the early stage of the flat biopsy of adult coeliac disease, being superficially similar to the findings in some patients with that disorder treated with a gluten-free diet. There was, however, no evidence in the six patients biopsied a second time of any significant change in the histological findings other than towards normality even in patients who had suffered relapse. Indeed, in two patients biopsied for the first time 16 and 18 years after their initial illness, the jejunal mucosa was practically normal.

They also had in common a severe megaloblastic anaemia. The occurrence of comparable degrees of anaemia in adult coeliac disease is not usual, for only three severe cases were encountered in 65 patients with flat biopsies so far studied. This observation appears significant to us when the difference in folic acid absorption tests in the two groups is considered. In the patients we are presenting, folic acid appears to be absorbed readily even though the patients have a severe megaloblastic anaemia. In adult coeliac disease, folic acid absorption and excretion tests are grossly abnormal but haematological evidence of severe folic acid depletion is not common. Anderson, Belcher, Chanarin, and Mollin (1960), studying the absorption of tritium-labelled folic acid, noted that patients with idiopathic steatorrhoea who had little or no steatorrhoea or diarrhoea and 'presented with 
a mild or severe megaloblastic anaemia, often but not invariably absorbed borderline or normal amounts of 3H-folic acid'. They also noted some correlation between the severity of the atrophy of the jejunal mucosa and the severity of the defect in absorption of tritium-labelled folic acid.

Low serum levels of B12 have been noted by Mollin, Waters, and Harriss (1962) and by Johnson et al. (1962) in megaloblastic anaemia due to folic acid deficiency. They may reflect over-utilization of B12 in an effort to compensate for the defect in folic acid metabolism (Cox et al., 1962). The complete remission obtained by $\mathrm{B} 12$ alone in case 17 suggested initially that this patient was in some way different to the other patients. Mollin, Waters, and Harriss (1962) have noted that some patients with a folic acid deficiency and megaloblastic anaemia do make such a response, though usually it is only partial. The finding of gastric $\mathrm{HCl}$, normal $\mathrm{B} 12$ absorption, and normal gastric mucosa suggests that this patient is another such example. Neither the effect of antibiotics nor of a gluten-free diet has been tried on these patients and must await further study.

Significant differences were also noted in the glucose tolerance and xylose excretion tests. Though the incidence of hypoproteinaemia, hypocalcaemia, and iron deficiency was similar in this group and in patients with adult coeliac disease, the differences noted in the other findings seem to justify our belief that they are two different disease entities.

We have no adequate explanation at present to offer as to why these patients developed a severe megaloblastic anaemia in a relatively short time. The evidence provided by the folic acid absorption and excretion tests, together with the ready response to small doses of folic acid, rules out any failure of absorption as the cause. From a survey of their dietary histories, there appeared adequate supplies of pteroylglutamates. Anorexia was a symptom of the megaloblastic anaemia and not a precipitating factor. Whether the patients have some intrinsic enzymatic defect which finds difficulty in making these substances available for haematopoiesis is conjecture. If such a defect were present, it might be expected to find the patients in a state of chronic folic acid depletion. In this event superimposed infection, pregnancy, or drug administration might precipitate the megaloblastic anaemia. However, in this group of patients we were unable to detect such factors, and in any case the excretion of folic acid in the urine following an intramuscular injection does not support the concept of chronic depletion of folic acid in the tissues.
It might also be argued that it was not justifiable to present these patients together as a homogeneous group since eight had no steatorrhoea. However, if there is a basic intestinal defect common to all of them, it should be in the upper small intestine, the site where folic acid is absorbed. Therefore, some patients might well have sufficient remaining normal small intestine to allow the normal quantitative absorption of fat. For the present we believe it reasonable to group these patients together, presenting as they do a severe megaloblastic anaemia due to folic acid deficiency, normal absorption of Co58B12, free gastric $\mathrm{HC1}$, normal glucose tolerance and folic acid absorption test, and jejunal biopsies significantly different to those found in adult coeliac disease. For the purpose of this paper, the disorder has been designated temperate sprue, since some of the findings appear close to those encountered in tropical sprue. It is hoped that a more satisfactory term will be forthcoming when more is known of the causation of the acute folic acid deficiency encountered.

We wish to thank our colleagues in the United Birmingham Hospitals for their ready cooperation in allowing us to study many of these patients, and Dr. D. B. Brewer for his help with the biopsies. We should also tender our appreciation to Sister Tillotson and Dr. C. Tasman Jones for their assistance in many of the investigations. We are indetted to the Medical Research Endowment Fund of the United Birmingham Hospitals for personal grants to one of us (D.J.F.) and for the provision of much equipment and technical assistance.

\section{REFERENCES}

Anderson, B., Belcher, E. H., Chanarin, I., and Mollin, D. L. (1960). The urinary and faecal excretion of radioactivity after oral doses of H3-folic acid. Brit. J. Haemat., 6, 439-455.

Cooke, W. T. (1958). Adult coeliac disease and other disorders associated with steatorrhoea. Brit. med. J., 2, 261-265.

_, Fone, D. J., Cox, E. V., Meynell, M. J., and Gaddie, R. (1963). Adult coeliac disease. Gut, 4, 279.

-, Peeney, A. L. P., and Hawkins, C. F. (1953). Symptoms, signs, and diagnostic features of idiopathic steatorrhoea. Quart. $J$. Med., 22, 59-77.

Cox, E. V., Cooke, W. T., Meynell, M. J., and Gaddie, R. (1962). Effect of iron and folic acid administration in patients with megaloblastic anaemia and low serum B12 levels. In Vitamin B12 und Intrinsic Factor. 2. Europaisches Symposion (Hamburg, 1961), edited by H. C. Heinrich, p. 756-760. Enke, Stuttgart.

Fone, D. J., Cooke, W. T., Meynell, M. J., Brewer, D. B., Harris, E. L., and Cox, E. V. (1960). Jejunal biopsy in adult coeliac disease and allied disorders. Lancet, 1, 933-938.

Johnson, S., Swaminathan, S. P., and Baker, S. J. (1962). Changes in serum vitamin B12 levels in patients with megaloblastic anaemia treated with folic acid. J. clin. Path., 15, 274-277.

Mollin, D. L., Waters, A. H., and Harriss, E. (1962). Clinical aspects of the metabolic interrelationships between folic acid and vitamin B12. In Vitamin BJ2 und Intrinsic Factor. 2. Europaisches Symposion (Hamburg, 1961), edited by H. C. Heinrich, p. 737-7.55. Enke, Stuttgart. 